\title{
Effectiveness of HCV core antigen and RNA quantification in HCV-infected and HCV/HIV-1- coinfected patients
}

\author{
Lu Long ${ }^{1}$, Tao Shen ${ }^{1 *}$, Jian Gao ${ }^{1}$, Zhaojun Duan ${ }^{1}$, Hua Liang ${ }^{2}$ and Fengmin Lu ${ }^{1 *}$
}

\begin{abstract}
Background: The measurement of hepatitis $\mathrm{C}$ virus core antigen (HCV-coreAg) has been shown to be an indicator of active HCV infection. The aim of the present study was 1) to investigate the stability and effectiveness of HCV-coreAg and HCV-RNA quantification in HCV infection with or without HIV-1 coinfection, 2) to explore the association between the HCV-coreAg/HCV-RNA (Ag/RNA) ratio and the immune status in chronic HCV/HIV-1-coinfected patients.

Methods: A longitudinal investigation comprised of 227 HCV-monoinfected $(n=129)$ and HCV/HIV-1-coinfected ( $n=98$ ) patients was initiated in August 2009, and 139 (73 with HCV monoinfection and 66 with HCV/HIV-1 coinfection) were followed up in August 2012. Both HCV core antigen and HCV RNA quantification were determined on this cryopreserved plasma. HCV core antigen and HCV RNA quantification were performed subsequently. In addition, an in vitro experiment investigating the possibility of degradation of HCV components (core antigen and RNA) were conducted.

Results: Significant and stable correlations ( $p$ 0.001) were observed both in chronic HCV-monoinfected and HCV/ HIV-1-coinfected patients over the 3-year observation. Coinfected patients with immunocompromised condition had a significantly higher $(p<0.05) \mathrm{Ag} / \mathrm{RNA}$ ratios than those patients with immunocompetent condition both at two time points (2009 and 2012). Moreover, the Ag/RNA ratios were negatively correlated with CD4+ T-cell counts $(p<0.001)$. An in vitro experiment investigated the possibility of the slower degradation of HCV particles under HIV-related immunocompromised condition was conducted and the data demonstrated that the Ag/RNA ratios were significantly higher in HIV-1-positive plasma than in healthy plasma $(p=0.005)$ in this study.
\end{abstract}

Conclusions: Our longitudinal study indicated that the HCV-coreAg presented comparable dynamics over time as HCV RNA in chronic HCV-infected patients. Meanwhile, the HCV-coreAg/HCV-RNA ratio was closely associated with immune status in HCV/HIV-1-coinfected patients.

Keywords: CD4+ T-cell counts, Coinfection, HCV-coreAg, HCV-RNA, HCV/HIV-1, Ratio

\section{Background}

Hepatitis $\mathrm{C}$ virus ( $\mathrm{HCV})$ is one of the major causes of liver cirrhosis and hepatocellular carcinoma [1]. Approximately 170 million individuals around the world are chronically infected with $\mathrm{HCV}$ and 34 million individuals currently suffer from human immunodeficiency virus (HIV) [2-4]. $\mathrm{HCV} / \mathrm{HIV}-1$ coinfection is common due to their shared routes of transmission. In China, a higher prevalence rate

\footnotetext{
* Correspondence: taoshen@hsc.pku.edu.cn; lu.fengmin@hsc.pku.edu.cn 'Department of Microbiology and Center of Infectious Diseases, Peking University Health Science Center, 38 Xueyuan Road, Haidian District, Beijing 100191, China

Full list of author information is available at the end of the article
}

of coinfection in several provinces has been linked to unsanitary commercial blood [4-7]. In clinical practice, as a routine screening test for the diagnosis of $\mathrm{HCV}$ infection, anti-HCV assay has the disadvantage of failing to distinguish between active infection and prior infection that has resolved spontaneously or after antiviral treatment. In addition, false positive anti-HCV tests are often found in pregnant women and patients with nephrological or rheumatoid diseases [8]. On the other hand, our previous observation [9] hints false negative anti-HCV results are becoming more frequent in immunocompromised patients, particularly those with AIDS. 
Real-time RT-PCR is an alternative strategy that does not have this disadvantage. However, detection of $\mathrm{HCV}$ RNA by real-time RT-PCR requires skill, is timeconsuming, and is too expensive for primary hospitals, despite its merit in evaluating HCV replication $[10,11]$.

Another cheaper alternative in lieu of HCV-RNA detection is quantification of hepatitis $\mathrm{C}$ virus core antigen (HCV-coreAg). Our previous study [9] and others [12-17] have widely investigated the potential applicability of this strategy to the diagnosis of active HCV infection and monitoring of antiviral response, due to its correlation with RT-PCR, as well as its ease of automation. Despite these advantages, the further improvement for the detection limit of $\mathrm{HCV}$-coreAg assay is still highly desired [8]. Recently, Garbuglia et al. [18] demonstrated that $\mathrm{HCV}$-coreAg also represent an adequate tool for determining an active $\mathrm{HCV}$ infection in $\mathrm{HCV} / \mathrm{HIV}$ coinfected patients with different HCV genotyping. The present report describes a 3-year longitudinal study to further investigate the stability and effectiveness of HCV-coreAg and HCV-RNA quantification in HCV infection with or without HIV-1 coinfection.

\section{Methods}

\section{Study population}

The study, a longitudinal investigation of $227 \mathrm{HCV}$ monoinfected (129 persons) and HCV/HIV-1-coinfected (98 persons) patients, was initiated in August 2009. The patients were residents of a village in Shangcai county, Henan province in central China, with an adult population of 1,252. A high prevalence rate of blood-borne AIDS and chronic hepatitis $C$ in the same village was reported previously [19]. Of the 227 patients originally enrolled, 139 (73 with HCV monoinfection and 66 with $\mathrm{HCV} / \mathrm{HIV}-1$ coinfection) were followed up in August 2012; the other 88 were lost because of death or loss of contact. All the 139 persons were confirmed with positive reaction of plasma HCV RNA tests and no subject was found to turn HCV RNA negative at the end of follow-up. A flow diagram for recruited persons is illustrated in Figure 1. HCV infection was defined by positive anti-HCV response and positive results for HCV-RNA detection. HIV-1 infection was identified by positive anti-HIV responses. All recruited patients were negative for hepatitis B surface antigen ( $\mathrm{HBsAg}$ ) and had never received any forms of $\mathrm{HCV}$-specific antiviral therapy.

All HCV/HIV-1-coinfected patients had previously received regular or intermittent HIV-specific treatment using highly active antiretroviral therapy (HAART) consisting of two nucleoside reverse transcriptase inhibitors (NRTIs): azidothymidine (AZT) plus didanosine (ddI) ( 60\%); or stavudine (d4T) plus lamivudine (3TC) ( 40\%), and one non-nucleoside reverse transcriptase inhibitor (NNRTI): nevirapine (NVP). The treatment was provided through support from the China CARES (Community AIDS Resource and Education Services) program. All participants were interviewed by trained and qualified staff using a standardized questionnaire, including detailed general information, blood donation history, and usage of antiviral or antiretroviral drugs. The clinical backgrounds of the 139 followed-up patients are shown in Additional file 1: Table S1. The study was approved by the institutional review authorities of Peking University Health Science Center (Approval ID: PKUPHLL20090011). All patients provided written informed consent before enrollment in the study.

\section{Sample collection and clinical evaluation}

Serum and EDTA anticoagulant plasma were immediately stored in $-80^{\circ} \mathrm{C}$ after collection. Several liver function indexes, alanine aminotransferase (ALT), aspartate aminotransferase (AST), and $\gamma$ glutamyl transpeptidase $(\gamma-\mathrm{GT})$, total protein, albumin and bilirubin, were measured by traditional clinical standardized methods on Unicer Dxc 800 Synchron Clinical System (Beckman Coulter, Fullerton, CA, USA). Also, the fatty liver grades of recruited patients were evaluated by ultrasonography [20].

\section{HCV/HIV seropositive screening and confirmation}

Plasma HCV antibody was detected using the Abbott Architect anti-HCV assay (Abbott $\mathrm{GmbH} \& \mathrm{Co}$ KG, Wiesbaden, Germany); Anti-HCV status of all positive anti-HCV were confirmed by HCV-RIBA assay (Wantai Biological Pharmacy), which utilizes recombinant proteins (Core, NS3, NS4 and NS5) immobilized as individual bands onto test strips. The intensity of the HCV bands is scored in relation to the intensities of the internal IgG controls as 5 different levels: 0 (none),,,,++++++++++ , according to the manufacturer's instructions. The HIV-1 screening test was performed in the local center of diseases control and prevention (CDC) and was based on HIV-1 antibodies ELISA assay (GBI Biotech Co., Ltd., Beijing, China) and all positive tests were confirmed by HIV Blot 2.2 WB assay (HIV Blot 2.2 WB; Genelabs Diagnostics, Singapore).

\section{$\mathrm{HCV}$ core antigen quantification}

Plasma HCV-coreAg quantification was performed using a commercial chemiluminescent microparticle immunoassay (CMIA) (ARCHITECT HCV Ag Reagent Kit, Abbott Diagnostics, Abbott Park, USA) with a detection limit of $3 \mathrm{fmol} / \mathrm{L}$, according to the manufacturer's instructions.

\section{HCV-RNA quantification}

Plasma HCV-RNA measurements were performed using the Abbott Real-Time HCV Amplification Kit (Abbott Molecular Inc. Des Plaines, IL, USA) according to the manufacturer's instructions. The detection limit was 


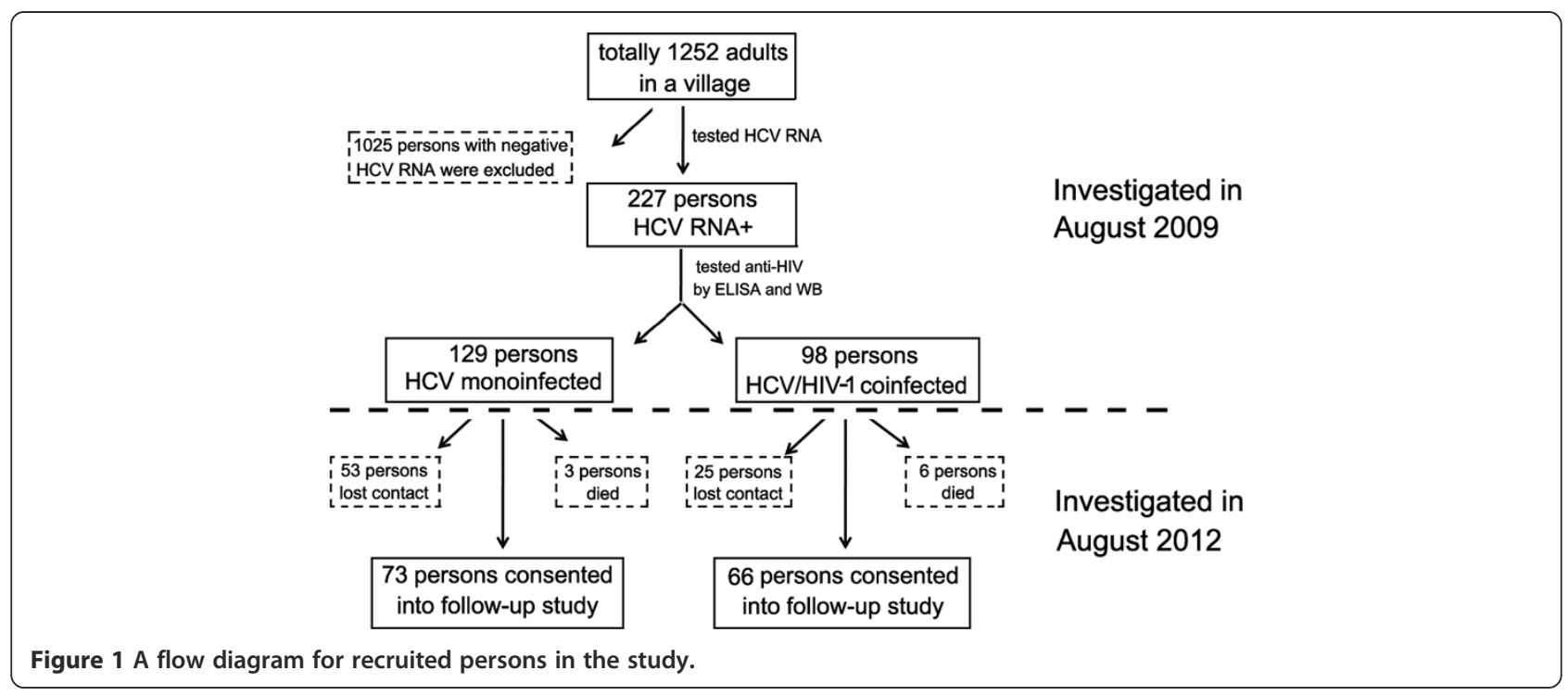

$30 \mathrm{IU} / \mathrm{mL}$, equivalent to $1.48 \log _{10} \mathrm{IU} / \mathrm{mL}$, with the $0.2 \mathrm{~mL}$ sample preparation procedure.

\section{CD4+/CD8+ T-cell counts}

All reagents were purchased from BD Biosciences (BD Biosciences, San Jose, CA) and CD4+/CD8+ T-cell counts were measured within 12 hours using a FACSCalibur (BD Biosciences, San Jose, CA).

\section{In vitro $\mathrm{HCV}$ particle degradation experiment}

Plasma samples were collected from seven HIV-1monoinfected patients and eight healthy individuals, with their informed consent, in 2012. For each patient, $3 \mathrm{~mL}$ plasma was equally divided into three $1.5 \mathrm{~mL}$ microtubes. Then, $200 \mu \mathrm{L}$ HCVcc stock (HCV-JFH1 virus, $1 \times 10^{7}$ copies $/ \mathrm{mL}$ ) was harvested from the cell culture supernatant of JFH1-tansfected Huh 7.5.1 cells (maintained in Dulbecco's modified Eagle's medium [DMEM] supplemented with $10 \%$ fetal bovine serum), and was added into each $1.5 \mathrm{~mL}$ microtube. DMEM medium was used as the blank control. HIV-1-infected plasma samples (and medium-only controls) were incubated in a $\mathrm{CO}_{2}$ incubator at $37^{\circ} \mathrm{C}$ for 0 and 12 hours, separately, and then frozen immediately until testing for HCV-coreAg and HCV-RNA. The clinical backgrounds of the seven HIV-1-monoinfected patients and eight healthy individuals are shown in Additional file 2: Table S2.

\section{Statistical analysis}

Descriptive statistics shown were the median with 25\% and $75 \%$ percentiles, as appropriate. Comparisons between groups were conducted using unpaired $t$ tests or Mann-Whitney U-tests. All statistical analyses were performed using GraphPad Prism for Windows, version 5.0 (GraphPad Software Inc., San Diego, CA). All p-values were two-tailed, and were considered significant when lower than 0.05 .

\section{Results}

The concentration of HCV-coreAg was highly correlated with HCV-RNA levels in HCV-monoinfected and HCV/HIV1-coinfected patients over 3-year observation

The present study confirmed that, in HCV-monoinfected patients, HCV-coreAg and HCV-RNA were significantly correlated at the two different time points $(2009, \mathrm{HCV}-1 \mathrm{~b}$ : $\mathrm{r}=0.802, \mathrm{p}<0.001$, HCV-2a: $\mathrm{r}=0.786, \mathrm{p}<0.001 ; 2012$, HCV-1b: $r=0.919, p<0.001$, HCV-2a: $r=0.944, p<0.001$, Figure 2A). Similarly, HCV-RNA and HCV-coreAg were also correlated, at both time points, in HIV-1-coinfected patients (2009, HCV-1b: $\mathrm{r}=0.841, \mathrm{p}<0.001$; HCV-2a: $\mathrm{r}=0.962, \mathrm{p}<0.001 ; 2012, \mathrm{HCV}-1 \mathrm{~b}: \mathrm{r}=0.706, \mathrm{p}<0.001$; HCV-2a: $r=0.899, p<0.001$, Figure $2 A)$. In addition, $100 \%$ of the HCV-RNA positive samples were also positive by the HCV-coreAg assay (data not shown).

\section{The dynamics of the changes in HCV-RNA and HCV-coreAg at two time points}

To clearly reflect the dynamics of the correlation between HCV-RNA and HCV-coreAg at two different time points, the differences in $\mathrm{HCV}$-coreAg concentration $(\triangle \mathrm{HCV}$-coreAg $=$ concentration at 2009-concentration at 2012) and HCV-RNA levels $(\triangle \mathrm{HCV}$-RNA = concentration at 2009-concentration at 2012) were calculated and analyzed. As shown in Figure 2B, a strong correlation $(\mathrm{r}=0.595, \mathrm{p}<0.001)$ was seen between $\triangle$ HCV-RNA and $\triangle \mathrm{HCV}$-coreAg in patients with HCV monoinfection, and a similar positive correlation was observed in patients with HCV/HIV-1 coinfection $(\mathrm{r}=0.844, \mathrm{p}<0.001)$. This result suggested that $\mathrm{HCV}$-coreAg and $\mathrm{HCV}$-RNA changed in parallel with each other over the 3-year observation. 

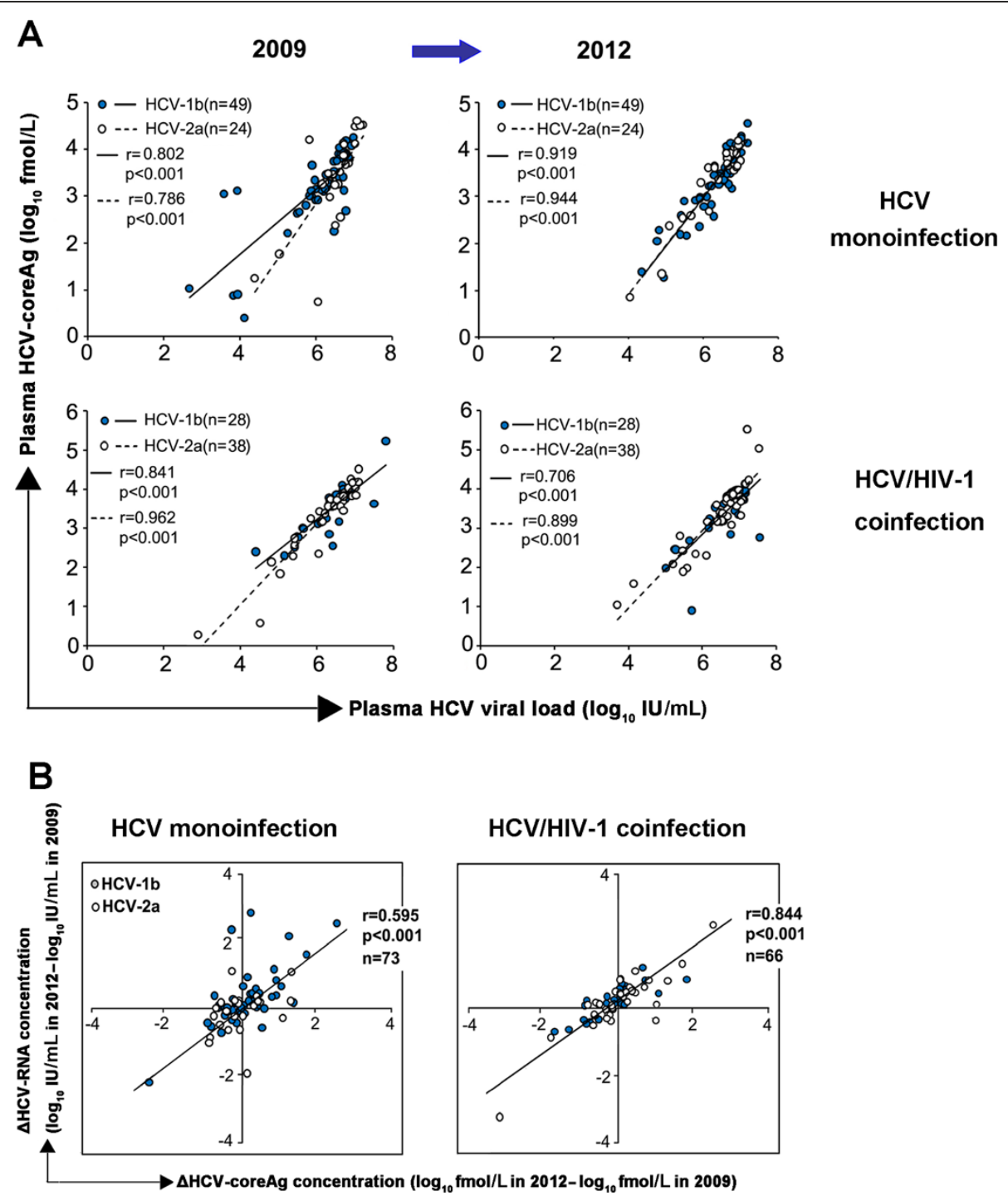

Figure 2 The correlation was showed between the concentration of hepatitis C virus core antigen (HCV-coreAg) and HCV-RNA at two time points. (A) The levels of HCV-coreAg were highly correlated with serum HCV-RNA load, both in HCV-monoinfected and HCV/HIV-1-coinfected patients in 2009 and 2012, for both HCV genotypes 1b (•) and 2a (o). (B) Correlation of $\triangle H C V$-coreAg concentration ( $\log _{10} \mathrm{fmol} / \mathrm{L}$ in $2012-\log _{10} \mathrm{fmol} / \mathrm{L}$ in 2009) and $\triangle \mathrm{HCV}$-RNA concentration ( $\log _{10} \mathrm{IU} / \mathrm{mL}$ in $2012-\log _{10} \mathrm{IU} / \mathrm{mL}$ in 2009) at two time points both in HCV-monoinfected and HCV/HIV1 -coinfected patients. Spearman's rank-correlation test was performed. All values are $\log _{10}$-transformed, $\mathrm{p}<0.05$ indicates significance.

Negative correlation between the ratios of HCV-coreAg to HCV-RNA and CD4+ T-cell counts in HCV/HIV-1-coinfected patients

Next, we explored the association between the ratio of the HCV-coreAg to the HCV-RNA (Ag/RNA) and immune status in $\mathrm{HCV} / \mathrm{HIV}-1$-coinfected patients. Interestingly, when the $\mathrm{HCV} / \mathrm{HIV}$-1-coinfected patients were divided into two groups according to variation in CD4+ T-cell counts at the two time points, the patients with $\mathrm{CD} 4^{2012} \geq \mathrm{CD} 4^{2009}$ showed lower $\triangle \mathrm{Ag} / \mathrm{RNA}$ ratios (ratio $^{2012}$ ratio $^{2009}$ ) than patients with $\mathrm{CD} 4^{2012}<\mathrm{CD} 4^{2009}$ ( $\mathrm{p}=0.001$, Figure 3A). Furthermore, significant negative correlations were observed between Ag/RNA ratios and CD4+
T-cell counts both in 2009 and 2012 (2009: $\mathrm{r}=-0.467$, $\mathrm{p}<0.001 ; 2012: \mathrm{r}=0.476, \mathrm{p}<0.001$, Figure 3B).

\section{HCV particle degradation in vitro}

The data presented above showed that the Ag/RNA ratios were negatively correlated with CD4+ T-cell counts. It is conceivable that the higher degradation rates of $\mathrm{HCV}$-RNA and/or the slower decay rate of HCV-coreAg under the HIV-related immunocompromised condition may be partially responsible for this. To support our hypothesis, an in vitro experiment investigating the possibility of degradation of HCV particles was conducted. The experiment was performed within the environment 


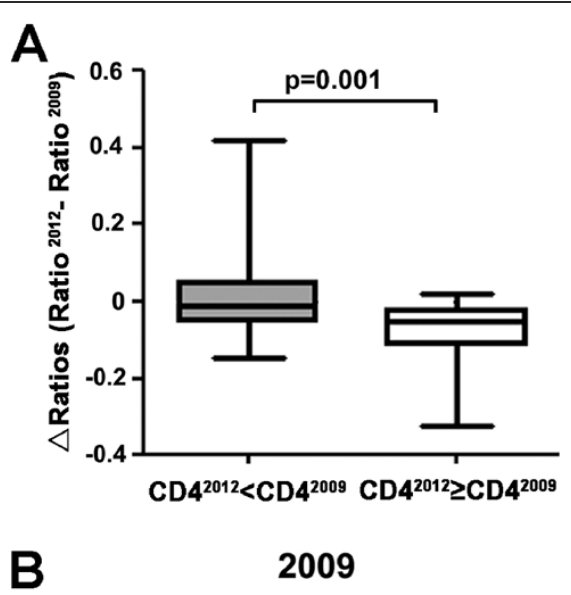

2012

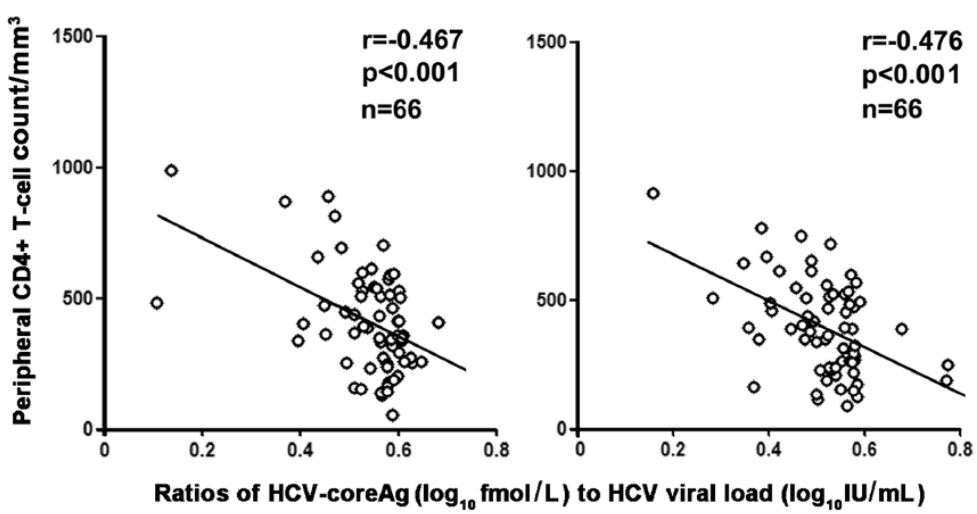

Figure 3 HIV-related immune dysfunction associated with the ratio of HCV-coreAg to HCV-RNA (Ag/RNA). Negative correlation between the ratio of HCV-coreAg to HCV-RNA (Ag/RNA) and CD4+ T-cell counts in HCV/HIV-1-coinfected patients. (A) $\triangle A$ g/RNA ratios (ratio ${ }^{2012}$ - ratio ${ }^{2009}$ ) were significantly lower in HCV/HIV-1-coinfected patients with CD4 $4^{2012} \geq C D 4^{2009}$ than in those with CD4 ${ }^{2012}<\mathrm{CD} 4^{2009}$. (B) Negative correlations between CD4+ T-cell counts and Ag/RNA ratios were seen both in 2009 and 2012. Mann-Whitney U-tests and Spearman's rank-correlation were performed in (A) and (B), separately, $\mathrm{P}<0.05$ indicates significance.

of healthy and HIV-1-positive plasma as shown in "materials and methods". These conditions mimic HCV-monoinfected and HCV/HIV-1-coinfected plasma, respectively, and are therefore suited to evaluate the degradation dynamics of the $\mathrm{HCV}$ core protein and RNA during incubation at $37^{\circ} \mathrm{C}$ for 12 hours.

After incubating at $37^{\circ} \mathrm{C}$ for 12 hours, the average HCV-RNA levels decreased to $33.49 \%, 54.92 \%$, and $73.16 \%$ of the initial levels in medium, healthy plasma, and HIV-1-positive plasma, respectively, whereas at the same time, the average $\mathrm{HCV}$-coreAg levels decreased to $9.16 \%, 46.16 \%$, and $42.45 \%$ of the initial levels. Decay rates of $\mathrm{HCV}$-RNA and $\mathrm{HCV}$-coreAg at 12 hours were significantly lower in medium than in healthy plasma (HCV-RNA: $\mathrm{p}<0.001, \mathrm{HCV}$-coreAg: $\mathrm{p}<0.001$ ) and in HIV-1-positive plasma (HCV-RNA: $\mathrm{p}<0.001$, HCVcoreAg: $\mathrm{p}<0.001$ ) (Figure 4A). The decay rate of HCVRNA in healthy plasma was significantly lower than in HIV-1-positive plasma $(p=0.035)$, while no similar difference was observed in the decay of HCV-coreAg ( $p>0.05)$. Further, we observed that the Ag/RNA ratios in HIV-1- positive plasma were significantly higher than in healthy plasma ( $p=0.005$, Figure 4B). Certainly, it must be noted that the influence of blood cells on degradation of $\mathrm{HCV}$ is not addressed in this in vitro experiment.

\section{Detection and analysis of anti-HCV antibody response}

In the Figure 5, the comparison of the anti-HCV Ab among three groups of recruited participants in 2009 survey (including $129 \mathrm{HCV}$-monoinfected subjects, 34 HCV/HIV-1 coinfected subjects with $\mathrm{CD} 4 \geq 500 / \mathrm{mm}^{3}$ and 64 coinfected subjects with $\mathrm{CD} 4<500 / \mathrm{mm}^{3}$ ) were performed by Architect anti-HCV assay and HCV-RIBA assay respectively. As shown in Figure $5 \mathrm{~A}$, the anti-HCV $\mathrm{Ab}$ titer of coinfection with $\mathrm{CD} 4<500 / \mathrm{mm}^{3}$ was the lowest level among three groups $(\mathrm{p}<0.001$ and $\mathrm{p}=0.004$, separately). Also, the HCV-RIBA data (Figure 5B) indicated that anti-HCV responses induced by Core, NS3, NS4 and NS5 proteins were highest in HCV monoinfected patients, to a less degree found in HCV/HIV coinfection with $\mathrm{CD} 4 \geq 500 / \mathrm{mm}^{3}$ and lowest in coinfection with $\mathrm{CD} 4<500 / \mathrm{mm}^{3}$. 

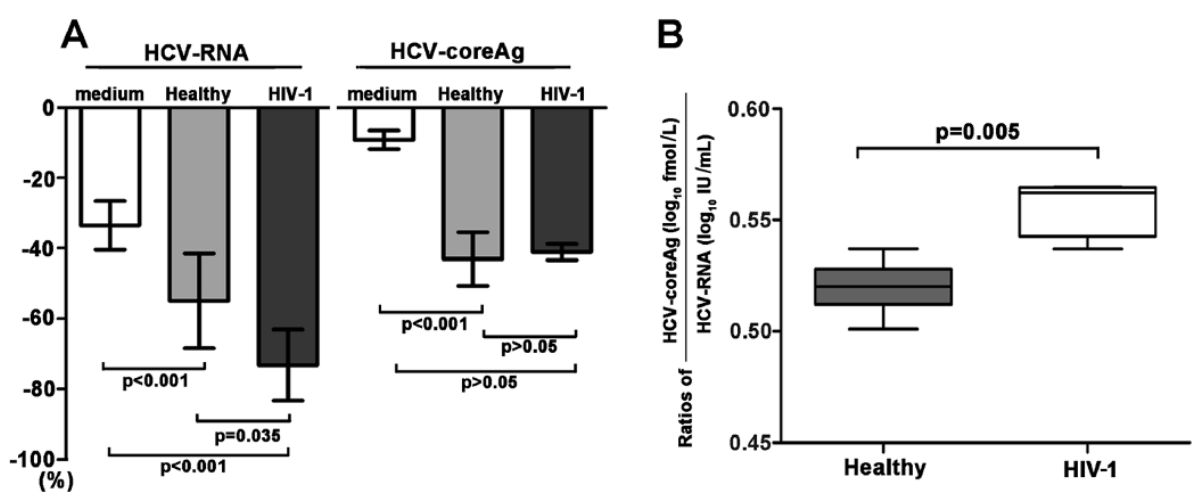

Figure 4 In vitro hepatitis $\mathrm{C}$ virus particle degradation experiment. Changes in the degradation dynamics of HCV-RNA and HCV- CoreAg, (A) in medium, HIV-1-positive, and healthy plasma after incubation at $37^{\circ} \mathrm{C}$ for 12 hours. The $\mathrm{X}$ axis indicates the degradation of HCV-RNA or HCV-coreAg at 12 hours, expressed as a percentage of the initial levels. (B) HCV-coreAg/HCV-RNA ratios at 12 hours in HIV-1-positive plasma were significantly higher than those in healthy plasma. Unpaired t tests and Mann-Whitney U-tests were performed, $p<0.05$ indicates significance.

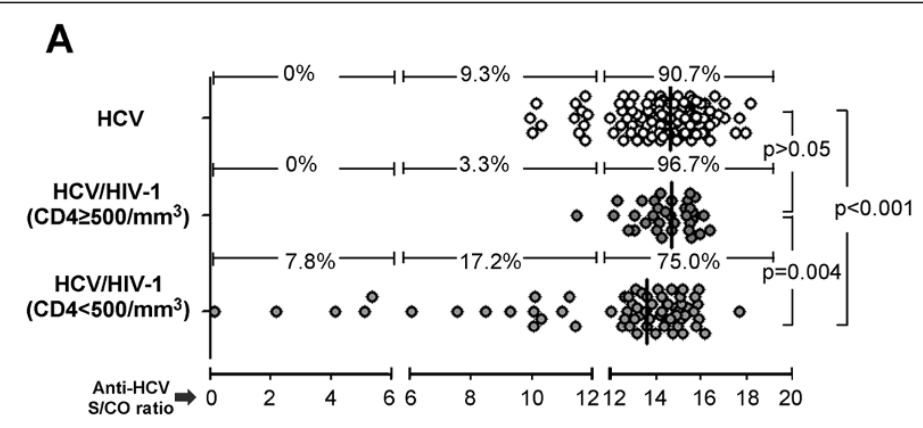

\section{B}
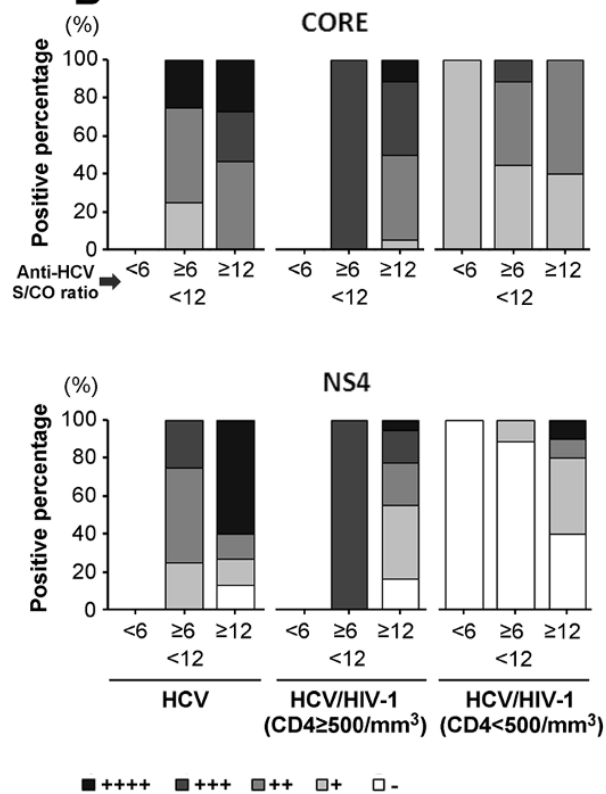

(\%)

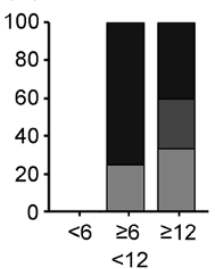

NS3

(\%)

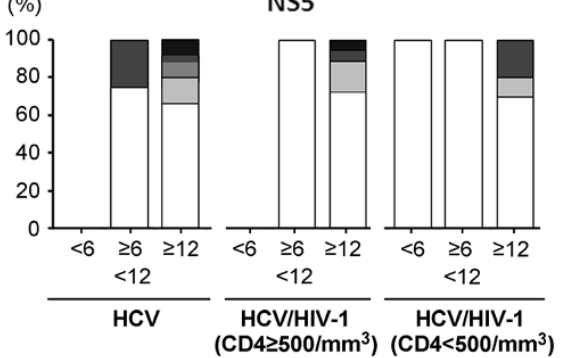

Figure 5 Anti-HCV status of HCV monoinfection, HCV/HIV coinfection with CD4 $\geq 500 / \mathrm{mm}^{3}$ and coinfection with $\mathrm{CD} 4<500 / \mathrm{mm}^{3}$ were performed by Architect anti-HCV assay and HCV-RIBA assay respectively. (A) S/CO ratios of anti-HCV antibody of HCV/HIV-1-coinfected patients with $\mathrm{CD} 4+\mathrm{T}<500 / \mathrm{mm}^{3}$ were significantly lower than coinfected patients with CD4+ T $\geq 500 / \mathrm{mm}^{3}$ and HCV-monoinfected patients. (B) Anti-HCV responses induced by Core, NS3, NS4 and NS5 proteins of HCV monoinfection, HCV/HIV coinfection with CD4 $\geq 500 / \mathrm{mm}^{3}$ and coinfection with CD4 $<500 / \mathrm{mm}^{3}$ were retested by HCV-RIBA assay. The intensity of the HCV bands is scored in relation to the intensities of the internal lgG controls as 5 different levels: 0 (none),,,,++++++++++ , according to the manufacturer's instructions. Mann-Whitney U-tests were performed, $p<0.05$ indicates significance. 


\section{Discussion}

Several studies conclude that HCV-coreAg determination using the ARCHITECT platform would be a useful strategy for monitoring $\mathrm{HCV}$ infection and discriminating periods with active viral replication from spontaneous clearances. This approach could be used as a supplement to response-guided antiviral therapy $[13,15]$. In our study, all HCV-RNA-positive samples were also positive for $\mathrm{HCV}$-coreAg, giving a detection rate of $100 \%$ by $\mathrm{HCV}$-coreAg. In accordance with the published data $[9,13,15,21]$, our data also showed a comparatively high diagnostic sensitivity for the HCV-coreAg quantitative assay.

In our longitudinal study, high correlations between HCV-RNA and HCV-coreAg were observed in both HCV-monoinfected and HCV/HIV-1-coinfected patients, for both genotypes $1 \mathrm{~b}$ and $2 \mathrm{a}$ of HCV. These observations confirm results from other published data based on the different cross-sectional studies [9,15-17,21-23]. Our findings also suggested that the correlation between $\mathrm{HCV}$ coreAg and HCV-RNA is relatively stable in the same group, even at different time points. Taken together, the $\mathrm{HCV}$-coreAg assay is a feasible alternative method for HCV-RNA determination.

It is believed that the amount of HCV-RNA is constantly proportional to the amount of $\mathrm{HCV}$-coreAg in complete viral particles. Christian et Al. [24] suggested that variability in the ratio of HCV-RNA and core protein could be an additional indicator for treatment follow-up, as well as providing information on HCV replication. Magali et al. [12] found that different HCVmonoinfected individuals had minor differences in the amount of core protein and HCV-RNA. Mederache et al. found that no significant difference in HCV-RNA/ $\mathrm{HCV}$-coreAg ratios between $\mathrm{HIV}-1 / \mathrm{HCV}-$, HBV/HCV-, and $\mathrm{HCV}$-infected hemodialysis patients [25]. However, the characteristics of variable $\mathrm{Ag} / \mathrm{RNA}$ ratios in different HCV/HIV-1-coinfected patients are not well understood. In present 3-year longitudinal study, we observed higher $\mathrm{Ag} / \mathrm{RNA}$ ratios in $\mathrm{HCV} / \mathrm{HIV}-1$-coinfected patients with lower CD4+ T-cell counts. Moreover, the Ag/RNA ratios were found to be negatively correlated with CD4+ T-cell counts in HCV/HIV-1-coinfected patients. These results indicated that differences in the levels of core protein and HCV-RNA are broadened in HCV/HIV-1-coinfected patients with declining $\mathrm{CD} 4+\mathrm{T}$-cell counts, though the underlying mechanism remains unclear. Some possible explanations are related to the idea that the kinetics of degradation of $\mathrm{HCV}$-coreAg and HCV-RNA in $\mathrm{HCV} / \mathrm{HIV}$ coinfection differ from those of HCV monoinfection. Accumulated literatures [26-29] have demonstrated that microbial translocation is a cause of systemic immune activation in chronic HIV infection, which characterized by higher levels of plasma bacterial DNA and LPS in
HIV-infected patients compared to healthy controls. Considering such phenomenon, we hypothesized that the disintegrated bacteria would probably release much more RNase into plasma of immunosuppressed HIV subjects. Consistent with this theory, our in vitro data supported the idea that the greater instability of HCVRNA in HIV plasma may partly account for the higher $\mathrm{Ag} / \mathrm{RNA}$ ratios in HCV/HIV-1-coinfected patients with lower CD4+ T-cell counts. Additionally, as shown in Figure 5, HCV/HIV-1-coinfected patients with an impaired immune system may produce fewer antibodies against $\mathrm{HCV}$-coreAg than $\mathrm{HCV}$-monoinfected patients. It is conceivable that anti-core antibodies might interfere with the detection of HCV-coreAg or shorten its half-life in circulation, which could be an alternative explanation for the different Ag/RNA ratios seen in coinfected patients. Thus, based on present observations, serum HCV-Ag quantitation might more reliably reflect the authentic level of $\mathrm{HCV}$ copies than $\mathrm{HCV}$ RNA determination in $\mathrm{HCV} / \mathrm{HIV}$-coinfected patients with compromised immunity. However, we could neither prove nor disprove this hypothesis through the experiment described here, because the HIV-positive and healthy plasma did not contain anti-HCV antibodies. On the other hand, other plasma components, such as viral proteins, lipids, and microRNA may also affect the decay of HCV-RNA and core protein.

\section{Conclusions}

In conclusion, our longitudinal study indicated that the $\mathrm{HCV}$-coreAg presented comparable dynamics as $\mathrm{HCV}$ RNA over time in chronic HCV-infected patients. These data also suggested that the Ag/RNA ratio had unique characteristics that varied among different infectious statuses and was negatively correlated with CD4+ T-cell count in HCV/HIV-1-coinfected patients.

\section{Additional files}

Additional file 1: Table S1. The clinical characteristics of $73 \mathrm{HCV}$ monoinfected and $66 \mathrm{HCV} / \mathrm{HIV}$-1-coinfected patients enrolled in our longitudinal study.

Additional file 2: Table S2. The clinical characteristics of 7 HIV-1monoinfected patients and 8 healthy individuals enrolled in the in vitro study.

\section{Abbreviations}

HCV: Hepatitis C virus; HIV: Human immunodeficiency virus; HCV-coreAg: Hepatitis c virus core antigen; HBsAg: Hepatitis B surface antigen; Ab: antibody; HAART: Highly active antiretroviral therapy; NRTIs: Nucleoside reverse transcriptase inhibitors; AZT: Azidothymidine; ddl: Didanosine; d4T: Stavudine; NNRTI: Non-nucleoside reverse transcriptase inhibitor; NVP: Nevirapine; ALT: Alanine aminotransferase; AST: Aspartate aminotransferase; Y-GT: $\gamma$ glutamyl transpeptidase; CMIA: Chemiluminescent microparticle immunoassay.

\section{Competing interests}

The authors declare that they have no competing interests. 


\section{Authors' contributions}

TS and FL conceived the study, drafted the experimental protocol and manuscript. LL, JG and ZD performed the experiments and analyzed the data. TS and $\mathrm{LL}$ and $\mathrm{HL}$ contributed to writing, reviewing, and revising the paper. All authors interpreted the data and critically reviewed drafts of the manuscript. All authors edited and approved the final manuscript.

\section{Acknowledgments}

We thank all patients and volunteers who participated in the study and all staff in Shangcai Center for Disease Control and Prevention for their help in collection of samples.

This work was supported by grants from the National Natural Science Foundation of China (81271826), the China "863" project (2012AA022605), the National Science and Technology Major Project for Infectious Diseases (2012ZX10002003 and 2012ZX10002005) and the National Science Foundation of Beijing (7122108)

\section{Author details}

'Department of Microbiology and Center of Infectious Diseases, Peking University Health Science Center, 38 Xueyuan Road, Haidian District, Beijing 100191, China. ${ }^{2}$ State Key Laboratory for Infectious Disease Prevention and Control, National Center for AIDS/STD Control and Prevention, China CDC, Collaborative Innovation Center for Diagnosis and Treatment of Infectious Diseases, Beijing 100026, China.

Received: 8 May 2014 Accepted: 22 October 2014

Published online: 05 November 2014

\section{References}

1. Williams R: Global challenges in liver disease. Hepatology 2006, 44:521-526.

2. Shepard CW, Finelli L, Alter MJ: Global epidemiology of hepatitis C virus infection. Lancet Infect Dis 2005, 5:558-567.

3. Soriano V, Puoti M, Sulkowski M, Cargnel A, Benhamou Y, Peters M, Mauss S, Brau N, Hatzakis A, Pol S, Rockstroh J: Care of patients coinfected with HIV and hepatitis C virus: 2007 updated recommendations from the HCV-HIV International Panel. AIDS 2007, 21:1073-1089.

4. Soriano V, Vispo E, Labarga P, Medrano J, Barreiro P: Viral hepatitis and HIV co-infection. Antiviral Res 2010, 85:303-315.

5. Dou Z, Chen RY, Wang Z, Ji G, Peng G, Qiao X, Fu J, Meng X, Bulterys M, Ma $Y$, Zhao $Y$, Wang N, Zhang F: HIV-infected former plasma donors in rural Central China: from infection to survival outcomes, 1985-2008. PLoS One 2010, 5:e13737.

6. Wu Z, Liu Z, Detels R: HIV-1 infection in commercial plasma donors in China. Lancet 1995, 346:61-62.

7. Ji G, Detels R, Wu Z, Yin Y: Correlates of HIV infection among former blood/plasma donors in rural China. AIDS 2006, 20:585-591.

8. Ottiger C, Gygli N, Huber AR: Detection limit of architect hepatitis C core antigen assay in correlation with HCV RNA, and renewed confirmation algorithm for reactive anti-HCV samples. J Clin Virol 2013, 58:535-540.

9. Shen T, Chen X, Zhang W, Xi Y, Cao G, Zhi Y, Wang S, Xu C, Wei L, Lu F, Zhuang $\mathrm{H}$ : A higher correlation of HCV core antigen with CD4+ T cell counts compared with HCV RNA in HCV/HIV-1 coinfected patients. PLOS One 2011, 6:e23550.

10. National Institutes of Health: NIH Consensus Statement on Management of Hepatitis C: 2002. NIH Consens State Sci Statements 2002, 19:1-46.

11. Strader DB, Wright T, Thomas DL, Seeff LB: Diagnosis, management, and treatment of hepatitis C. Hepatology 2004, 39:1147-1171.

12. Bouvier-Alias M, Patel $K$, Dahari H, Beaucourt S, Larderie P, Blatt L, Hezode C, Picchio G, Dhumeaux D, Neumann AU, McHutchison JG, Pawlotsky JM: Clinical utility of total HCV core antigen quantification: a new indirect marker of HCV replication. Hepatology 2002, 36:211-218.

13. Park Y, Lee JH, Kim BS, Kim do Y, Han KH, Kim HS: New automated hepatitis $C$ virus (HCV) core antigen assay as an alternative to real-time PCR for HCV RNA quantification. J Clin Microbiol 2010, 48:2253-2256.

14. Loggi E, Cursaro C, Scuteri A, Grandini E, Panno AM, Galli S, Furlini G, Bernardi M, Galli C, Andreone P: Patterns of HCV-RNA and HCV core antigen in the early monitoring of standard treatment for chronic hepatitis C. J Clin Virol 2013, 56:207-211.

15. Vermehren J, Susser $S$, Berger A, Perner D, Peiffer $K H$, Allwinn $R$, Zeuzem $S$, Sarrazin C: Clinical utility of the ARCHITECT HCV Ag assay for early treatment monitoring in patients with chronic hepatitis $C$ genotype 1 infection. J Clin Virol 2012, 55:17-22.

16. Medici MC, Furlini G, Rodella A, Fuertes A, Monachetti A, Calderaro A, Galli S, Terlenghi L, Olivares M, Bagnarelli P, Costantini A, De Conto F, Sainz M, Galli C, Manca N, Landini MP, Dettori G, Chezzi C: Hepatitis C virus core antigen: analytical performances, correlation with viremia and potential applications of a quantitative, automated immunoassay. J Clin Virol 2011, 51:264-269.

17. Mederacke I, Wedemeyer H, Ciesek S, Steinmann E, Raupach R, Wursthorn K, Manns MP, Tillmann HL: Performance and clinical utility of a novel fully automated quantitative HCV-core antigen assay. J Clin Virol 2009, 46:210-215.

18. Garbuglia AR, Monachetti A, Galli C, Sabatini R, Ferreri ML, Capobianchi MR, Bagnarelli P: HCV core antigen and HCV-RNA in HIV/HCV co-infected patients with different HCV genotypes. BMC Infect Dis 2014, 14:222.

19. Zhang W, Hu D, Xi Y, Zhang M, Duan G: Spread of HIV in one village in central China with a high prevalence rate of blood-borne AIDS. Int J Infect Dis 2006, 10:475-480.

20. Saadeh S, Younossi ZM, Remer EM, Gramlich T, Ong JP, Hurley M, Mullen KD, Cooper JN, Sheridan MJ: The utility of radiological imaging in nonalcoholic fatty liver disease. Gastroenterology 2002, 123:745-750.

21. Miedouge M, Saune K, Kamar N, Rieu M, Rostaing L, Izopet J: Analytical evaluation of HCV core antigen and interest for HCV screening in haemodialysis patients. J Clin Virol 2010, 48:18-21.

22. Kuo YH, Chang KC, Wang JH, Tsai PS, Hung SF, Hung CH, Chen CH, Lu SN: Is hepatitis $\mathrm{C}$ virus core antigen an adequate marker for community screening? J Clin Microbiol 2012, 50:1989-1993.

23. Ross RS, Viazov S, Salloum S, Hilgard P, Gerken G, Roggendorf M: Analytical performance characteristics and clinical utility of a novel assay for total hepatitis C virus core antigen quantification. J Clin Microbiol 2010, 48:1161-1168

24. Schuttler CG, Thomas C, Discher T, Friese G, Lohmeyer J, Schuster R, Schaefer S, Gerlich WH: Variable ratio of hepatitis C virus RNA to viral core antigen in patient sera. J Clin Microbiol 2004, 42:1977-1981.

25. Mederacke I, Potthoff A, Meyer-Olson D, Meier M, Raupach R, Manns MP, Wedemeyer H, Tillmann HL: HCV core antigen testing in HIV- and HBVcoinfected patients, and in HCV-infected patients on hemodialysis. J Clin Virol 2012, 53:110-115.

26. Mussini C, Galli L, Lepri AC, De Luca A, Antinori A, Libertone R, Angarano G, Bonfanti P, Castagna A, D'Arminio Monforte A: Incidence, timing, and determinants of bacterial pneumonia among HIV-infected patients: data from the ICONA Foundation Cohort. J Acquir Immune Defic Syndr 2013, 63:339-345

27. Buchacz K, Baker RK, Palella FJ Jr, Chmiel JS, Lichtenstein KA, Novak RM, Wood KC, Brooks JT: AIDS-defining opportunistic illnesses in US patients, 1994-2007: a cohort study. AIDS 2010, 24:1549-1559.

28. Brenchley JM, Price DA, Schacker TW, Asher TE, Silvestri G, Rao S, Kazzaz Z, Bornstein E, Lambotte O, Altmann D, Blazar BR, Rodriguez B, TeixeiraJohnson L, Landay A, Martin JN, Hecht FM, Picker LJ, Lederman MM, Deeks SG, Douek DC: Microbial translocation is a cause of systemic immune activation in chronic HIV infection. Nat Med 2006, 12:1365-1371.

29. Jiang W, Lederman MM, Hunt P, Sieg SF, Haley K, Rodriguez B, Landay A, Martin J, Sinclair E, Asher Al, Deeks SG, Douek DC, Brenchley JM: Plasma levels of bacterial DNA correlate with immune activation and the magnitude of immune restoration in persons with antiretroviral-treated HIV infection. J Infect Dis 2009, 199:1177-1185.

doi:10.1186/s12879-014-0577-1

Cite this article as: Long et al:: Effectiveness of HCV core antigen and RNA quantification in HCV-infected and HCV/HIV-1-coinfected patients. BMC Infectious Diseases 2014 14:577. 